\title{
Bioactive Peptides from Tempeh Using PeptideCutter's Cleavage
}

\author{
Badrut Tamam ${ }^{1 *}$, Dahrul Syah ${ }^{2}$, Hanifah Nuryani Lioe ${ }^{2}$, Maggy T. Suhartono ${ }^{2}$, Wisnu Ananta \\ Kusuma $^{3}$, Suratiah ${ }^{4}$
}

${ }^{1}$ Nutrition Department, Polytechnic of Health, Ministry of Health, Denpasar 80224, Indonesia

${ }^{2}$ Department of Food Science and Technology, Faculty of Agricultural Engineering and Technology, IPB University, Bogor 16680, Indonesia

${ }^{3}$ Department of Computer Science, Faculty of Mathematics and Natural Science, IPB University, Bogor 16680, Indonesia

${ }^{4}$ Nursing Department, Polytechnic of Health, Ministry of Health, Denpasar 80224, Indonesia

\section{${ }^{*}$ Equally contributed}

\section{Article history:}

Submission October 2020

Revised November 2020

Accepted December 2020

*Corresponding author:

E-mail:

badruttamam_70@yahoo.com

\begin{abstract}
Tempeh is an Indonesian traditional fermented food with rich nutrition and bioactive components. Rhizopus sp, especially Rhizopus oligosporus), lactic acid bacteria (Lactobacillus sp.), and yeast are microorganisms involved in Tempeh fermentation. An interesting offer of Bioinformatics (in silico method) as a supporting tool in molecular biology studies has emerged, such as in protein cleavage. This study utilized PeptideCutter application on ExPASy Bioinformatics portal (https://web.expasy.org/peptide_cutter/) to cleave soy proteins glycinin G1, G2, $\mathrm{G} 3, \mathrm{G} 4, \mathrm{G} 5, \beta$-conglycinin- $\alpha$ chain, and $\beta$ chain using available enzymes in the application with two simulations. Simulation I was conducted using enzyme complex produced by Lactobacillus sp. and Rhizopus oligosporus, while simulation II was used enzyme complex produced by Lactobacillus sp., Rhizopus oligosporus, and Klebsiella pneumonia. Simulation I was conducted using enzyme complex produced by Lactobacillus sp. and Rhizopus oligosporus, while simulation II was used enzyme complex produced by Lactobacillus sp., Rhizopus oligosporus, and Klebsiella pneumoniae. A total of 58 peptides was found from the simulation I and higher than simulation I (41 peptides). The bioactive peptides by the cleavages using PeptideCutter tool were dominated with dipeptides and only three peptides were in the form of tripeptides, namely Leu-Leu-Phe (glycinin G1), Val-Val-Phe (glycinin G5), and Arg-His-Lys ( $\beta$-conglycinin- $\alpha$ chain). Bioactive peptides with antihypertensive and antidiabetic properties were mostly found in this in silico method of soybean cleavage.
\end{abstract}

\section{Introduction}

Bioactive peptides are defined as protein fragments with amino acid sequences. Several biological activities are found in bioactive peptides, such as antioxidant, antihypertensive, antithrombotic, antiadipogenic, antimicrobial, anti-inflammatory, and immunomodulatory effects. Bioactive peptides are generally encrypted in the amino acid sequences of a food protein consisting of 2 to 20 amino acids or more than 20 amino acids [1]. Peptides are not active in storage proteins; however they should be released through proteolysis to activate their functional properties. Korhonen and Pihlanto reported that there are several proteolysis methods to produce bioactive peptides: 1) fermentation by proteolytic microorganisms, 2) digestion of food proteins in vivo, or 3) in vitro hydrolysis using various proteolytic enzymes [2]. One of the

\section{How to cite:}

Tamam, B., Syah, D., Lioe, HN., Suhartono, MT., Kusuma, WA., Suratiah (2020). Bioactive Peptides from Tempeh Using PeptideCutter's Cleavage. Bioinformatics and Biomedical Research Journal 3(2)35-40. doi: 10.11594/bbrj.03.02.05 
most popular fermentation products in Indonesia is Tempeh.

Tempeh is produced by the activities of several microorganisms on soybean substrate. A total of $40 \%$ glycinin (11S globulin) and $30 \% b$ conglycinin (7S globulin) are soy's major proteins. Other proteins in soybeans are Kunitz and Bowman-Birk trypsin inhibitors, lectins (hemagglutinin), lipoxygenase, sucrose linked protein, and $\alpha$ amylase [3,4]. Glycinin (molecular weight/MW $320-375 \mathrm{kDa})$ is composed of 5 subunits (G1, G2, $\mathrm{G} 3, \mathrm{G} 4$, and G5), while $\beta$-conglycinin (MW 150$200 \mathrm{kDa})$ consists of four subunits $(\alpha, \alpha, \beta$, and $\gamma)$. Rhizopus sp. (especially Rhizopus oligosporus), lactic acid bacteria (Lactobacillus sp.) and yeast are microorganisms involved in soybean fermentation, especially to Tempeh [5,6]. Proteolytic enzymes secreted by these microorganisms cleave soy protein into peptides during Tempeh fermentation [7]. One of the contaminant bacteria present in Tempeh fermentation is Klebsiella pneumoniae. It synthesizes vitamin B12 [8]. Recently, the bioinformatics approach has grown rapidly as a tool in molecular biology for protein cleavage. Bioinformatics reduces laboratory costs and and time [9].

ExPASy PeptideCutter retrieved from https://web.expasy.org/peptide_cutter/ is a popular bioinformatics application in protein cleavage [10]. The PeptideCutter provides 27 proteolytic enzymes that plays an important rolein cutting the polypeptide chain of a protein. Peptides formed from cleavage using PeptideCutter are synchronized with the BIOPEP database (www.uwm.edu.pl/biochemia/index.php/pl/biopep) for bioactivity prediction. BIOPEP, developed by the University of Warmia and Mazury (UWM) has become a favoured tool in identifying bioactive peptides. Information provided by BIOPEP-UWM includes sequences, biological activity, chemical mass, $\mathrm{IC}_{50}$, and other important information of peptides [11].

Based on in vitro analysis, bioactive peptides were obtained from Tempeh by extraction, separation, purification, and identification [12]. Meanwhile, the offer of in silico method in facilitating identification of bioactive peptides is interesting. Therefore, this study aimed to evaluate cleavage of soy protein, especially Tempeh production and to identify bioactive peptides from the in silico from the in silico approach using enzymes derived from the Brenda database (www.brenda-enzymes.org).

\section{Methods}

The proteins in soybeans namely glycinin G1, G2, G3, G4, G5, $\beta$-conglycinin of chain $\alpha$ and chain $\beta$ were used as cleavage substrate. Soy protein sequences were obtained from UniProtKB (http://www.uniprot.org) and the ExPASy bioinformatics portal (http://www.expasy.org).

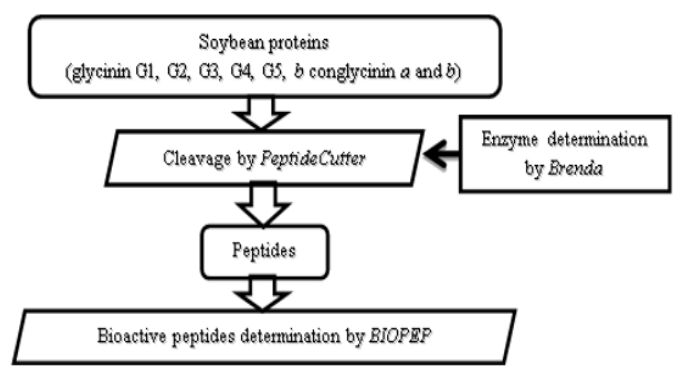

Figure 1.Algorithm of determination of bioactive peptides from soybean proteins using Bioinformatics

In silico approach was used in this study following with several steps. Determining the main soybean proteins, exploring enzymes generated from microorganisms from Brenda database, simulating protein cleavage by PeptideCutter, and determining the peptides bioactivity by BIOPEP (Figure 1). Molecular weights of peptide sequences were calculated using PepDraw application (www.enalut.ude/-biochem/WW/PepDraw/).

Determination of enzymes play an important role in protein cleavage using Brenda database (www.brenda-enzymes.org). Enzymes were produced by Lactobacillus sp., Rhizopus oligosporus (the dominant microorganism in making Tempeh) and Klebsiella pneumoniae (contaminant bacteria). Simulations of the protein cleavage in soybean (glycinin G1, G2, G3, G4 and G5 and $\beta$ conglycinin of chain $\alpha$ and chain $\beta$ ) using the PeptideCutter software (https://web.expasy.org/peptide_cutter/) available on the ExPASy portal were performed in two types of simulations. Simulation that was conducted using enzymes complex produced by Lactobacillus sp. and Rhizopus oligosporus, while simulation II used complex enzymes produced by Lactobacillus sp., Rhizopus oligosporus, and Klebsiella pneumoniae (Table 1). In addition, determination of peptide biofunctionalities 
was performed using BIOPEP database (www.uwm.edu.pl/biochemia/index.php/pl/biopep).

Table 1.Proteolytic enzymes on the PeptideCutter application in both simulations

\begin{tabular}{cc}
\hline $\begin{array}{c}\text { Simulation I } \\
\text { (enzymes from }\end{array}$ & $\begin{array}{c}\text { Simulation II } \\
\text { (enzymes from }\end{array}$ \\
Lactobacillus sp. and & Lactobacillus sp., \\
Rhizopus oligosporus) & Rhizopus oligosporus, \\
& and Klebsiella \\
& pneumoniae) \\
\hline Asp N Endopeptidase & Asp N Endopeptidase \\
Asp N Endopeptidase + & Asp N Endopeptidase + \\
N terminal Glu & N terminal Glu \\
Glutamyl endopeptidase & Glutamyl \\
& endopeptidase \\
Proline endopeptidase & Proline endopeptidase \\
Trypsin & Trypsin \\
& Chymotrypsin \\
\hline
\end{tabular}

\section{Result and Discussion}

\section{Determination of protein-cutting enzymes}

Enzymes had an important role in the process of cutting soy proteins by PeptideCutter software. Enzymes produced by Lactobacillus sp., Rhizopus oligosporus (a dominant microorganism in Tempeh production), and Klebsiella pneumoniae (a contaminant microorganism) were referred to the Brenda database (www.brenda-enzymes.org). Proteolytic enzymes found in Lactobacillus sp., Rhizopus oligosporus, and Klebsiella pneumoniae were obtained from the Brenda database.

\section{Determination of soy protein sequences}

Soy protein sequences were obtained from the SwissProt database (http://www.uniprot.org)and the ExPASy portal. Soy protein of glycinin G1 (GY1 strain), G2 (GY2 strain), G3 strain GY3), G4 (GY4), G5 (N/A strain), $\beta$ conglycinin chains $\alpha$ (N/A strain) and $\beta$ conglycinin chain $\beta$ (Strain CG-4) were main precursors of bioactive peptides from soybeans. The process of searching for soy protein sequences was conducted by entering SwissProt accession number (P04776, P04405, P11828, P02858, P04347, P11827 and P25974 for glycinin G1, G2, G3, G4, G5, $\beta$-conglycinin chain $\alpha$ and $\beta$-conglycinin $\beta$ chain, respectively) on http://www.uniprot.org. The main soy protein sequences were obtained from the https://www.uniprot.org/uniprot/?query=glycinin\&sort=score.

\section{Peptides from cleavage using PeptideCutter}

Soy protein sequences were obtained from the SwissProt database (http://www.uniprot.org) and cleaved using enzymes available at PeptideCutter (https://web.expasy.org/peptide cutter/). Proteolytic enzymes on PeptideCutter involved in simulation I (produced by Lactobacillus sp. and Rhizopus oligosporus) were Asp N Endopeptidase, Asp N Endopeptidase + N terminal Glu, Glutamyl endopeptidase, Proline endopeptidase, and trypsin. Meanwhile in simulation II (produced by Lactobacillus sp., Rhizopus oligosporus, and Klebsiella pneumonia) were Asp N endopeptidase, Asp $N$ Endopeptidase $+N$ terminal Glu, Glutamyl

Table 2. Total number of peptides, bioactive peptides, and percentage of bioactive peptides as a result of PeptideCutter cleavage according to the BIOPEP database

\begin{tabular}{|c|c|c|c|c|c|c|c|c|}
\hline \multirow[t]{2}{*}{ No } & \multirow[t]{2}{*}{ Soy protein } & \multirow[t]{2}{*}{$\begin{array}{l}\text { Number of } \\
\text { amino acid } \\
\text { residues }\end{array}$} & \multicolumn{2}{|c|}{$\begin{array}{c}\text { Peptides } \\
<1.500 D a \\
\text { Simulation }\end{array}$} & \multicolumn{2}{|c|}{$\begin{array}{c}\text { Bioactive } \\
\text { peptides } \\
\text { Simulation }\end{array}$} & \multicolumn{2}{|c|}{$\begin{array}{l}\text { \% Bioactive } \\
\text { peptides* } \\
\text { Simulation }\end{array}$} \\
\hline & & & I & II & I & II & I & II \\
\hline 1 & Glycinin G1 & 495 & 67 & 93 & 11 & 20 & 16,4 & 21,5 \\
\hline 2 & Glycinin G2 & 485 & 63 & 90 & 13 & 21 & 20,6 & 23,3 \\
\hline 3 & Glycinin G3 & 481 & 58 & 91 & 11 & 24 & 19,0 & 26,4 \\
\hline 4 & Glycinin G4 & 562 & 73 & 103 & 20 & 21 & 27,4 & 20,4 \\
\hline 5 & Glycinin G5 & 516 & 69 & 91 & 13 & 19 & 18,8 & 20,9 \\
\hline 6 & $\beta$-conglycinin $\alpha$ chains & 605 & 103 & 125 & 11 & 20 & 10,7 & 16,0 \\
\hline 7 & $\beta$-conglycinin $\beta$ chains & 439 & 69 & 92 & 11 & 17 & 15,9 & 18,5 \\
\hline & Average & & 72 & 98 & 13 & 20 & 18 & 21 \\
\hline
\end{tabular}


endopeptidase, Proline endopeptidase, Trypsin and Chymotrypsin.

The number of peptides from cleavage simulation I (enzymes of Asp N endopeptidase, Asp $N$ Endopeptidase $+N$ terminal Glu, Glutamyl endopeptidase, Proline endopeptidase, and Trypsin), had molecular weights below 1,500 Da. Besides, the glycinin $\mathrm{G}$ number of peptides $\mathrm{G}$ for $1, \mathrm{G} 2, \mathrm{G} 3$, G4, G5, $\beta$-conglycinin chain $\alpha$, and $\beta$-conglycinin chain $\beta$ was $67 ; 63 ; 58 ; 73 ; 69 ; 103$ and 69 peptides, respectively. Meanwhile, II simulation II (enzymes of Asp $N$ Endopeptidase $+N$ terminal Glu, Glutamyl endopeptidase, Proline endopeptidase, Trypsin, and Chymotrypsin) was 94; 91; 92; $104 ; 92 ; 126$ and 92 peptides, respectively, as shown on Table 2 .

These findings indicated that the more proteolytic enzymes involved in protein cleavage, the more peptides generated. The presence of contaminant microorganisms such as Klebsiela pneumoniae produced protease enzymes and contributed in cutting process of soy protein sequences. Therefore, the amount of peptides increased. The highest number of peptides was found rom soy protein $\beta$-conglycinin chain $\alpha$ followed by glycinin G4. Our results were in accordance with the length of amino acid (AA) residue by the soy protein. The lengths of amino acid from $\beta$ conglycinin $\alpha$ chain and glycinin G4 were 639 AA and $562 \mathrm{AA}$, respectively. The average of peptides below 1,500 Da resulted from in silico cleavage in simulation I and simulation II was $92 \%$ and $99 \%$, respectively.

\section{Bioactive peptides resulted from PeptideCutter cleavage}

The average number of bioactive peptides resulted from PeptideCutter cleavage in simulation I and II were 13 and 20, respectively, as shown in Table 2. Our study demonstrated that the more protease enzymes in the process of protein cleavage, the more peptides and bioactive peptides were produced. The highest percentage of bioactive peptides in simulation I and simulation II was derived from Glycinin G4 and Glycinin G3 (27.4\% and $26.4 \%$, respectively). The largest contribution of bioactive peptides by glycinin G4 was due to the second largest number of amino acid residues (562 amino acid residues), following $\beta$ conglycinin $\alpha$ chains (605 amino acid residues). Interestingly, glycinin G3 had only 481 amino acid residues in simulation II. It indicated that glycinin G3 is the most bioactive peptides compared to other soy proteins.

Various sequence lengths of peptides were found from the cleavage using enzyme complex on PeptideCutter application against soy protein (glycinin G1, G2, G3, G4, G5, $\beta$-conglycinin $\alpha$ chain and $\beta$-conglycinin $\beta$ chain). The results indicated that mostly the number of sequences was below 1,500 Da. $\beta$-conglycinin $\alpha$ chains had the largest number of peptides (103 and 125 peptides in simulation 1 and in simulation 2, respectively).

\section{Biofunctionality of bioactive peptides through in silico}

Peptides from the cleavage using PeptideCutter were confirmed their functional properties through the BIOPEP database (www.uwm.edu.pl/biochemia/index.php/pl/bio-

pep). The bioactive peptides and their activities were found on BIOPEP database as presented in Table 3.

Based on both simulation, antihypertensive property of the peptides was dominant in soybean proteins cleavage followed by antidiabetic and antioxidant properties. Antitumor and ion flow regulator had few numbers. Gibbs et al. revealed that Tempeh had ACE inhibition, antithrombotic, surface tension, and antioxidative properties [13]. Additionally, Tamam et al. also found bioactive peptides with antihypertensive, antidiabetic, antioxidant, and antitumor properties in different three Tempeh producers, following extraction and separation with LC/MS [12].

Some of the bioactive peptides are similar, such as Pro-Leu (antihypertention); Pro-Phe and His-Phe (antidiabetics); Lys-Pro and Thr-Tyr (antioxidant), as highlighted and underlined on Table 3. Our result demonstrated cleavage of proteins by using PeptideCutter provided general characteristics of bioactive peptides through in vitro protein hydrolysis.

\section{Conclusion}

PeptideCutter and BioPep could be beneficial to evaluate the presence of bioactive peptides in food or other materials. The PeptideCutter, composed with some enzymes, cleaved the sequence of amino acids to generate peptides and bioactive peptides. The more protein enzymes involved in the process of protein cleavage generated the more peptides and bioactive peptides. The BioPep containing bioactive peptide database 
Table 3. Bioactivity of bioactive peptides (simulations I and II) identified using the BIOPEP database

\begin{tabular}{|c|c|c|c|c|}
\hline \multirow[t]{2}{*}{ Bioactivities } & \multicolumn{2}{|l|}{ Simulation I } & \multicolumn{2}{|l|}{ Simulation II } \\
\hline & Bioactive Peptides & Numbers & Bioactive Peptides & Numbers \\
\hline Antihipertention & $\begin{array}{l}\text { Arg-Pro; Gly-Lys; Lvs-Pro; } \\
\text { Leu-Arg; Val-Phe; Asp-Glv; } \\
\text { Leu-Gln; Gly-Arg; Pro- } \\
\text { Gln; Phe-Arg; Leu-Asn; } \\
\text { Trp-Phe; Ile-Arg; Asn-Lys; } \\
\text { Pro-Arg; Val-Arg; Val-Lys; } \\
\text { His-Pro; Ala-Arg; Gly-Ser; } \\
\text { Ile-Leu; Asp-Ala; Gln-Lys; } \\
\text { Pro-Leu }\end{array}$ & 24 & $\begin{array}{l}\text { Leu-Leu-Phe; Ala-Phe; } \\
\text { Thr-Tre; Arg-Pro; Ser- } \\
\text { Tyr; Ile-Thy; Asn-Phe; } \\
\text { Gly-Lys; Lys-Pro; Leu- } \\
\text { Arg; Val-Phe; Asp-Gly; } \\
\text { Leu-Gln; Gly-Arg; Pro- } \\
\text { Gln; Ala-Pro; Ser-Phe; } \\
\text { Glu-Glu; Ala-Tyr; Leu- } \\
\text { Asn; Thr-Phe; Ile-Arg; } \\
\text { Tyr-Pro; Asn-Lys; Pro- } \\
\text { Arg; Val-Lys; His-Pro; } \\
\text { Gln-Phe; Val-Arg; Val- } \\
\text { Val-Phe; Ala-Arg; Gly- } \\
\text { Ser; Asp-Tyr; Ile-Leus } \\
\text { Asp-Ala; Asp-Phe; Gln- } \\
\text { Lys; Pro-Leu }\end{array}$ & 38 \\
\hline Antidiabetic & $\begin{array}{l}\text { Arg-Pro; Asp-Arg; Phe- } \\
\text { Leu; Lys-Pro; Thr-Asn; } \\
\text { Pro-Gln; Phe-Arg; Gln- } \\
\text { Gln; Leu-Asn; Thr-Phe; Ile- } \\
\text { Arg; Ser-Pro; Trp-Gln; Trp- } \\
\text { Arg; Ser-Lys; Thr-Arg; Leu- } \\
\text { His; Val-Arg; Val-Lys; Val- } \\
\text { Ala; Phe-Asn; His-Pro; Sex- } \\
\text { Pro; Ile-Leu; Pro-Leu; Tyr- } \\
\text { Arg; Gln-Ile }\end{array}$ & 27 & $\begin{array}{l}\text { Ala-Phe; Thr-Trp; Arg- } \\
\text { Pro; Ser-Tyr; Ile-Tyr; Asp- } \\
\text { Arg; Asn-Phe; Asn-Asn; } \\
\text { Gln-Gln; Thy-Leu; Lys- } \\
\text { Pro; Thy-Asn; Pro-Gln; } \\
\text { Ala-Pro; Ser-Phe; Asp- } \\
\text { Arg; His-Phe; Ala-Tyr; } \\
\text { Val-Val; Leu-Asn; Thr- } \\
\text { Phe; Ile-Arg; Thr-Tyr; } \\
\text { Ser-Lys; Ser-Pro; Thr- } \\
\text { Arg; Leu-His; Val-Lys; } \\
\text { Val-Ala; Thr-Tvr; His- } \\
\text { Pro; Gln-Phe; Val-Arg; } \\
\text { Ile-Leus; His-Ser; Pro-Phe; } \\
\text { Pro-Leu; Gln-Ile }\end{array}$ & 38 \\
\hline Antioxidant & $\begin{array}{l}\text { Lys-Pro; Leu-Lys; Ile-Arg; } \\
\text { Leu-His; Arg-His-Lys }\end{array}$ & 5 & $\begin{array}{l}\text { Leu-Lys; Lys-Pro; Ala- } \\
\text { Lys; Ile-Arg; Thr-Tyr; } \\
\text { Leu-His; Thr-Tyr; Arg- } \\
\text { His-Lys }\end{array}$ & 8 \\
\hline Antitumor & Ile-Arg & 1 & Ile-Arg & 1 \\
\hline Ion flow regulator & - & & Asp-Tyr & 1 \\
\hline
\end{tabular}

revealed that the biofunctionalities of bioactivepeptides found in soybean hydrolysis (Tempeh production) were antihypertension, followed by antidiabetics, antioxidant, and antitumor. Bioinformatics approach could contribute in initial screening of the number and potential bioactive peptides in protein cleavage.

\section{Acknowledgement}

This work was supported by the Ministry of Health of Indonesian Republic (Grant No. HK.02.02/H.V/SK/360/2015).

\section{References}

1. Ryan JT, Ross RP, Bolton D, Fitzgerald GF, Stanton C (2011) Bioactive peptides from muscle sources: meat and fish. Nutrients. 3:765-791. https://doi.org/10.3390/nu3090765.

2. Korhonen H, Pihlanto A (2006) Bioactive peptides: production and functionality. Int Dairy J. 16:945-960. https://doi.org/10.1016/j.idairyj.2005.10.012.

3. Herman EM, Schmidt MA (2016) The potential for engineering enhanced functional-feed soybeans for sustainable aqua $\begin{array}{llll}\text { culture feed. Front Plant Sci. 7:440. } & \end{array}$ https://doi.org/10.3389/fpls.2016.00440.

4. Gomes LS, Senna R, Sandim V, Silva-Neto MAC, Perales JEA, Zingali RB, Soares MR, Fialho E (2014) Four conventional soybean [Glycine max (L.) Merrill] seeds exhibit different protein profiles as revealed by proteomic analysis. J Agric $\begin{array}{lll}\text { Food Chem. 62:1283-1293. } & \end{array}$ https://doi.org/10.1021/jf404351g. 
5. Efriwati, Suwanto A, Rahayu G, Nuraida L (2013) Population dynamics of yeasts and Lactic Acid Bacteria (LAB) during tempeh production. Hayati J Biosci. 20:57-64. https://doi.org/10.4308/hjb.20.2.57.

6. Barus T, Suwanto A, Tri Wahyudi A, Wijaya H (2008) Role of bacteria in tempe bitter taste formation: microbiological and molecular biological analysis based on 16S rRNA gene. $\mathrm{Mi}$ crobiol Indones. 2:17-21. https://doi.org/10.5454/mi.2.1.4.

7. Tunçel G, Göktan D (1990) Effect of different methods of soaking soya beans on the growth of Bacillus cereus, Klebsiella pneumoniae and Staphylococcus aureus in tempeh.
Food
Agric.
53:287-296.

https://doi.org/10.1002/jsfa.2740530302.

8. Holton TA, Vijayakumar V, Khaldi N (2013) Bioinformatics current perspectives and future directions for food and nutritional research facilitated by a Food-Wiki database. Trends Food Sci Technol. 34:517.https://doi.org/10.1016/j.tifs.2013.08.009.

9. Udenigwe CC (2014) Bioinformatics approaches, prospects and challenges of food bioactive peptide research. Trends Food Sci Technol. 36:137-143. https://doi.org/10.1016/J.TIFS.2014.02.004.

10. Udenigwe CC, Gong M, Wu S (2013) In silico analysis of the large and small subunits of cereal $\mathrm{RuBisCO}$ as precursors of cryptic bioactive peptides. Process Biochem. 48:1794-1799. https://doi.org/10.1016/J.PROCBIO.2013.08.013.

11. Minkiewicz P, Iwaniak A, Darewicz M (2019) BIOPEP UWM database of bioactive peptides: current opportunities. Int J Mol Sci. 20:5978. https://doi.org/10.3390/ijms20235978.

12. Tamam B, Syah D, Suhartono MT, Kusuma WA, Tachibana S, Lioe HN (2019) Proteomic study of bioactive peptides from tempe. $J \quad B i o s c i \quad$ Bioeng. 128:241-248. https://doi.org/10.1016/j.jbiosc.2019.01.019.

13. Gibbs BF, Zougman A, Masse R, Mulligan C (2004) Production and characterization of bioactive peptides from soy hydrolysate and soy-fermented food. Food Res Int. 37:123-131. https://doi.org/10.1016/J.FOODRES.2003.09.010. 